\title{
The Land of Forgetting (Krajina zabudnutia)
}

Author: Anton Baláž

First Published: 2000

Translations: Hebrew (Eretz Hashichecha, 2015); Hungarian (A feledés földje, 2016).

About the Author: Anton Baláž (1943) is a Slovak prose writer, television and film screenwriter, radio playwright and publicist. After 1989 he started to work as the editor-in-chief of Slovenský denník. In the first year of the independent Slovak Republic (1993) he worked in the office of the President of the Slovak Republic. Baláž's work is very varied, but one important trend can be observed - it is preoccupied with less known topics of Slovak history. In the second half of the 1990s, Baláž returned thematically to the Jewish past, specifically to the Holocaust of the Slovak Jewish community. His work focuses on the first postwar years. It concentrates on the fate of the Jews who survived the horrors of concentration camps and then tried to reintegrate into ordinary life and to find a new sense of life. He followed the fates of Jews since the 1960s, but decided to write about this topic only in the second half of the 1990s.

Further Important Publications: Tábor padlých žien (1993, The Camp of Fallen Women; novel); Ofélia nie je mŕtva (2003, Ophelia Is Not Dead; radio play); Transporty nádeje (2010, Transports of Hope; nonfiction); Prehovor, Ezachiel (2012, Speak Out, Ezechiel; novel); Portréty prežitia (2014, Portraits of Survival; short stories); Povedz slovo čisté (2017, Say It Clearly; novel).

\section{Content and Interpretation}

The novel is set in the first years after World War II. The plot of the novel mainly takes place in Bratislava, in a Jewish quarter, but also in Vienna, where one of the main characters (Miriam) regularly goes to equip groups of Jews emigrating to Israel. On the basis of the description of the events, it can be assumed that it is in 1949. In retrospect flashbacks, the author described the war and Holocaust memories of Erna and Miriam which these two characters personally witnessed. That is why, they have to deal in the postwar years with the traumas they still carried from the war trauma of survivors.

The main characters are Erna and Miriam, two young Jews who survived the horror of the Holocaust in the concentration camp Auschwitz. Miriam survived thanks to Erna. During the Holocaust, Miriam lost her entire family and the flat they had lived in before the war. Miriam got employed by the Palestinian Office to help the surviving Jews find a new home in the new land of the Jews in Israel. She tries to justify her own survival, to get rid of her guilt towards her dead family members. Erna decides to leave Slovakia in the postwar period when the population between Hungary a Slovakia is

Ә Open Access. ( 2021 Monika Adamická, published by De Gruyter. (cc) BY-NC-ND This work is licensed under a Creative Commons Attribution-NonCommercial-NoDerivatives 4.0 License. https://doi.org/10.1515/9783110671056-055 
being exchanged, and she moves to Hungary. Now she is trying to escape from Hungary to Vienna through Slovakia, because she was forced to testify against the former Hungary minister László Rajk. In the trial with Rajk she had to testify that she was receiving information from him which she handed over to the Israeli Secret Service.

The other character is Albert Kalina (Aaron Katz) who is the head of the Palestinian Office. Although he is a character inspired by the real person Ludovit Kalina, the novel is a fictitious depiction of his destiny. Baláž devised his story on the basis of the probable fate of Jews, who were threatened by a long-term prison sentence for Zionism. Therefore the fictional Kalina ended his life by suicide. In the novel Kalina lost his family in a concentration camp where he advised them to go, because he did not know that the camps were the camps of death.

The novel begins at the Palestinian Office where a photographer named Jakub brings photographs of a Jewish wedding for Miriam. However, the Palestinian Office is already being watched by the State Security at that time. But it is already at a time when the Iron Curtain is starting to emerge across Europe, and emigration is becoming more and more complicated. Jakub soon finds out that he is under surveillance by the State Security after the inspectors and cultural consultants appear in his flat, an open studio, and warn him about topics that are banned.

Miriam meets Erna with whom she had spent eight months in Auschwitz, while working with Hungarian Jewish refugees. They have been separated during the death march. Erna suffers from a phobia of dirt after being in Auschwitz. Miriam decides to help her with her emigration to America. Erna spends a night in Jakub's flat and between Jakub, Erna, and Miriam, a kind of love triangle merges.

Jewish transports to Israel begin to be complicated by the fact that people were convinced that the Jews were exporting gold and jewellery from Slovakia, so they are cruelly checked at the border. It means yet another dishonour and degradation for them.

After Jakub accepts a position as a government photographer, in addition to the humiliation of Jews, he feels resistance against the state and himself, because he had contributed to the decrial of Jews. After destroying this state order, he decides to escape from Slovakia. Jakub and Miriam join the German transport from Slovakia to Germany. Miriam does not leave to Erec Israel like the other Jews, but stays in Germany, which might remind her of the horrors of the Holocaust. But she realises that Auschwitz would go with her anywhere. "I will still bring Auschwitz with me...” (p. 152). Kalina decides to end his life by suicide.

\section{Main Topics and Problems}

The author's books with the topic of Jewry were based on the archival documents of Ministry of the Interior, personal experience of those who survived and who he personally met, as well as the case files of some participants in the Zionist Trial. The Zionist Trial was a political trial with the employees of the Ministry of Interior and Palestinian Office who were involved in organising aliyah. They were prosecuted in the 
years 1952 and 1953 in the trials against bourgeois nationalists, accused of treason and other crimes against the socialist regime. They were imprisoned for nine to eighteen years.

The novel The Land of Forgetting is, according to the literary scientist and critic Mária Bátorová, unique to its kind in the Slovak literature, whether from the point of view of Jewish history in Slovakia, or describing the practical life of Orthodox Jews, their customs, traditions, the status of men and women.

Baláž's novel was inspired by the story of sisters Pavla and Eugenia Schreiber who survived Auschwitz. Pavla Schreiber, later Rodan, was the mother of Martin Rodan, one of his classmates at the Comenius University in Bratislava. The sisters were taken in the first transport from Slovakia (Poprad) on 25th March 1942. Their personal experience from the death camp was also reflected in the trauma of nudity, a topic that is an important part of the novel.

The sisters were the first ones who managed to report from Auschwitz what was happening in the camp. As a part of a propaganda event for the Red Cross in 1943, they could send gifts to relatives. The sisters made a wooden box with a secret bottom into which they put a report about the camp. The gift was sent to Budapest, where they understood their message and read the report in the main Budapest synagogue.

The author also deals extensively with the traumas that the surviving Jews had taken with them from the concentration camps. In the case of Miriam, it is a phobia of nudity, in the case of Erna it is a phobia of dirt. Miriam's phobia of nudity prevents her from being a full-fledged woman, preventing her from touching a man. Her phobia stems from the forced nudity she was exposed to in Auschwitz. With the help of Erna, in Auschwitz she learned to use her naked body only as a tool for survival.

Her own irrational fear of being nude is in strong contrast to the voluntary nudity of willing prostitutes she sees on the streets of Bratislava after the war. After the night spent with Jakub, she feels she is out of her trauma and phobia of nudity, she is a strong woman again.

Erna suffers from a different trauma, she does not care about her nudity because she did not experience the abhorrent nudity when she arrived in Auschwitz when only the skeletons of women were waiting. And she did not experience the mocking and abhorrent views of the German guards. However, Erna suffers from a phobia of dirt that prevents her from sleeping under her blanket. Again and again, she felt the horror of touching unclean things. After the war in Budapest, this fear was partly overcome, but her subsequent visit to Tel Aviv convinced her that dirt was not just about Auschwitz but it was related to culture, especially to the culture of the East. Under the influence of this trauma she is afraid of emigrating to Israel, it would be the death of her to live in such dirt. She decides to move to America. She overcomes her phobia in Jakub's flat when she is forced to cover herself with a blanket which is dirty in her opinion after the arrival of the inspectors, because she has to pretend she is his mistress. Then she finds out that if she decides to touch the dirty thing herself, it is not too bad, she can overcome it. 


\section{Cited Works}

Baláž, A. (2000). Krajina zabudnutia. Bratislava: Slovenský spisovatel'.

\section{Further References}

Baláž, A. (2017). Osvienčim v mojom románe Krajina zabudnutia a v jeho reálnom predobraze. In: M. Hrbácsek, ed., Židovský kultúrny fenomén v stredoeurópskom kontexte II. Zsidó kultúra közép-európai kontextusban II. Galanta: ART Danubius, pp. 71-75. Farkašová, E. (2019). Môj tip. Anton Baláž: Krajina zabudnutia. Available at: http://www.litcentrum.sk/recenzie/anton-balaz-krajina-zabudnutia [Accessed: 04.04.2019]. Kamenec, I. (2015). Medzi umeleckou licenciou a historiografickou rekonštrukciou. Anton Baláž: Portréty prežitia. Romboid, 50/I(5-6), pp. 77-79. Pospíšil, I. (2016). Anton Baláž: Portréty prežitia. Slovenské pohl’ady, 132/IV(4), pp. 148-149. 